Arab Univ. J. Agric. Sci., Ain Shams Univ., Cairo, Egypt

\title{
Effect of Growing Medium, Fertilization and Biostimulant Treatments on Growth and Flowering of Potted Gerbera (Gerbera Jamesonii Cv. Jaguar Yellow)
}

\section{Islam AA Ali ${ }^{1 *}$, Ayman F Abou-Hadid², Sohier E Hassan², Ahmed AM Abdelhafez ${ }^{3}$, Mohamed H Ramadan ${ }^{2}$}

1- Arid Lands Agricultural Graduate Studies and Research Institute, Ain Shams Univ, Cairo, Egypt

2- Horticulture Dept, Fac of Agric, Ain Shams Univ, P.O. Box 68, Hadayek Shoubra 11241, Cairo, Egypt

3- Agric. Microbiology Dept, Fac of Agric, Ain Shams Univ, P.O. Box 68, Hadayek Shoubra 11241, Cairo, Egypt

*Corresponding author: somaa4220@gmail.com

Received 10 September, 2020

\section{Abstract}

The current study was aimed to investigate the effect of different fertilization and biostimulant treatments on growth and flowering of Gerbera (Gerbera jamesonii $c v$. Jaguar Yellow) plant under unheated plastic greenhouse conditions. This study was carried out for two successive seasons of 2016/2017 and $2017 / 2018$ at the farm of the Arid lands Agriculture graduated studies and Research Institute (ALARI), Shoubra Elkheima area, Qalyobia governorate, Egypt. The experiment were laid out in a completely randomized design (CRD) with 3 replications, and the end results have been subjected to analysis of variance (ANOVA). Freshly extracted gerbera seedling have been planted into pots filled with peatmoss + sand (1:1), peatmoss + sand + vermicompost (1:1:1), peatmoss + sand + compost (1:1:1) with or without $250 \mathrm{ml}$ of Azotobacter + Azospirllum mixture, as biostimulant, and slow-release NPK (4.2g) or fast-release NPK $(2.5 \mathrm{~g})$ fertilizers to each plant, to determine the effect of fertilizer, biostimulant and growing medium types on the production of potted gerbera. Growth and flowering characteristics were measured. Results indicated that medium combination of sand + vermicompost + peatmoss (1:1:1) with biostimulant, regardless of the fertilizer type, gave significantly increased results in all measurements, compared to all other combinations. Plants grown in medium supplemented with biostimulant and fast-release fertilizer, gave flowers with good qualities While the medium combination sand + vermicompost + peatmoss (1:1:1) with biostimulant in combination with either one of NPK mineral fertilizers (fast-release fertilizer and slow release fertilizer) gave significantly increased results in most parameters, shown in higher total vegetarian and quality when combined with slow release fertilizer than fast-release fertilizer. Under this treatment, number of leaves per plant was (24.8), number of daughter plants/pot (5.3/plant), Leaf greenness (SPAD) (59.00), number of flower (1.28), flower head diameter $(8.3 \mathrm{~cm})$ and flower stalk diameter was $(2.72 \mathrm{~mm})$. These records were all significantly higher than other treatments.

Keywords: Gerbera jamesonii cv., Jaguar Yellow, Vermicompost, Compost, Azotobacter, Azospilrllum

\section{Introduction}

Gerbera (Gerbera jamesonii) is one of the foremost critical cut-vegetation, efficiently developed under semi controlled conditions. Its advantage is due having huge range in coloration and shape of the blossom. The cut sprouts when placed in water, stay fresh for a reasonable period of time. Gerbera belongs to the family "Compositae". Plants are stemless and delicate lasting herbs, take off radical, petiole, lanceolate, profoundly lobed, and in some cases rough (Florance Flora 2018). This species has a splendid capacity and destiny for production and exportation and the perfect Gerbera flowers have a wide range of petal colorings as red, white, 
orange, yellow etc., and the most popular cultivars are the red ones. Flowering time, flower yield per plant (5.5 to 8.0 flowers/per plant). Quality parameters, include stalk length, head diameter, may vary by means of developing seasons. Cultivation and production techniques include in soil or soilless systems (Moltay et al 1998, Maloupa and Gerasopoulos 1999, Özzambak, Zeybekoğlu 2004).

Growing medium plays a crucial position in seeds germination and for further boom and development of seedling. Among special media used is the vermicompost, which simultaneously provides sufficient oxygen and water to the roots, and is good storage of vitamins for the plant, balanced source of physical, chemical and biological necessities for good plant boom, lightweight to produce uniform plant growth (Atefe et al 2012). When vermicompost is mixed with peatmoss or different composted materials, the resulting product offers an excellent growing medium for plant life and facilitates them to propagate (Javed and Panwar 2013). Peatmoss improves water retention capability and has good nutrient content, infiltration rate, porosity, and hydraulic conductivity (Savithri and Khan 1993).

Use of a few coarse minerals has been found useful in improving drainage. Sand improves soil aeration and moisture retention. As a soil conditioner, sand can enhance the aeration and waterretaining characteristics of "sticky" soils, lessening complicated watering and chance of compaction, cracking and crusting of the soil (Anderson 2019). All those media are beneficial in this regard.

Biofertilizers are fertilizers composed of selected living cells of microbes which provide the plants with certain nutrients, growth promoters and other important biologically compounds (Leoni et al 2019). These microbes use extraordinary mechanisms to offer nutrients to the plants. Among them, some are atmospheric-nitrogen fixers, phosphate solubilizers and phosphate mobilizing (Bhat et al 2010), Addition of nitrogen-fixing bacteria to cultivation medium supports plants with free nitrogen, and other growth promoters (Brar et al 2012). They are renewable asset that may be utilized to replace portion of the chemical fertilizers. Use of biofertilizers is getting to be prevalent in view that of their nutritious esteem and comparatively lower natural impacts (Hari et al 2010). A study conducted on Gerbera jamesonii cv. Stanz plant, showed that inoculating the plant with a mix of mycorrhiza, Azotobacter chroococcum and Bacillus subtilus significantly increased vegetative growth characteristics, including leaf chlorophyll intensity, leaf area, concentration of mineral elements in gerbera leaves and flowering characters, including length of flower stalk, diameter of flower stalk, capitulum diameter, percentage of flower dry matter and number of flowers and vase life (Abdul-Latif and Mustafa 2019).

Soilless culture is an artificial means of providing plants with support and a reservoir for nutrients and water. Often called solution culture or water culture, the method was originally termed hydroponics (i.e., "water working") by W.F. Gericke in the 1930s. Recently, it has been widely in research facilities as a technique for studying plant nutrition. Various modifications of pure-solution culture have occurred. Gravel or sand is sometimes used in soilless systems to provide plant support and retain some nutrients and water. Soilless culture has been applied in horticulture and floricultural crops, has been used for several years in the Mediterranean and international locations (Maloupa et al 1992, Brun et al 2001). The Interaction between different growing media combinations and biofertilizers showed to have significant influence on growth parameters and root parameters of gerbera cv. Natasha under protected conditions (Swarupa et al 2019).

The use of farmyard manure as organic fertilizer is growing in Egypt due having great features such as being a quick-performing fertilizer, consequences on physical, chemical and biological residences of the soil, having impact as a supply of critical elements, capability to growth the availability of positive nutrients in addition to its impact in decreasing the leaching out of minerals (Suthar 2009). These authors showed the maximum values of some plant parameters, i.e., root length, shoot length, leaf length, bulb weight, number of cloves and number of leaves per plant were recorded in the (15 t/ha vermi compost $+50 \%$ NPK) treatmentplant. (Yassen and Khalid 2009) confirmed that mixture of farmyard manure and hen manure treatment enhanced vegetative characters, crop yield and NPK content of onion plants.

Therefore, the aim of this study was to investigate the impact of slow- and quick-release fertilizers, cultivation medium and biofertilizers on the production and quality of potted gerbera flower. 


\section{Materials and Methods}

\subsection{Location and duration}

The experiments of this research study were conducted in the experimental field of the Aird lands Agriculture Research Institute (ALARI), Shobra Elkheima area, Qalyobia governorate, Egypt (3007'01.6” N 31014'37.6"E) in two successive seasons of 2016/2017 and 2017/2018.

\subsection{Growing media types and treatments}

Three types of substrate were used in this experiment, in combination with biofertilizers and chemical fertilizers, making up 10 treatments, as follows:

\section{No. Growing medium Chemical Biofertilizer combination fertilizer}

T1 Peatmoss + Sand Fast-release without

T2 Peatmoss + Sand Fast-release added
T3 Peatmoss + Sand + Fast-release without Vermicompost

T4 Peatmoss + Sand + Fast-release added Vermicompost

T5 Peatmoss + Sand + Slow-release without Vermicompost

T6 Peatmoss + Sand + Slow-release added Vermicompost

T7 Peatmoss + Sand + Fast-release without Compost

T8 Peatmoss + Sand + Fast-release added Compost

T9 Peatmoss + Sand + Slow-release without Compost

T10 Peatmoss + Sand + Slow-release added Compost

Tables 1 \& 2 show the chemical and physical characteristics of the cultivation media used in the study. Table 1 illustrates the content of major elements, ions and cations of the growing media and Table 2 shows the physical analysis of the growing media.

Table 1. Major elements content of the cultivation media.

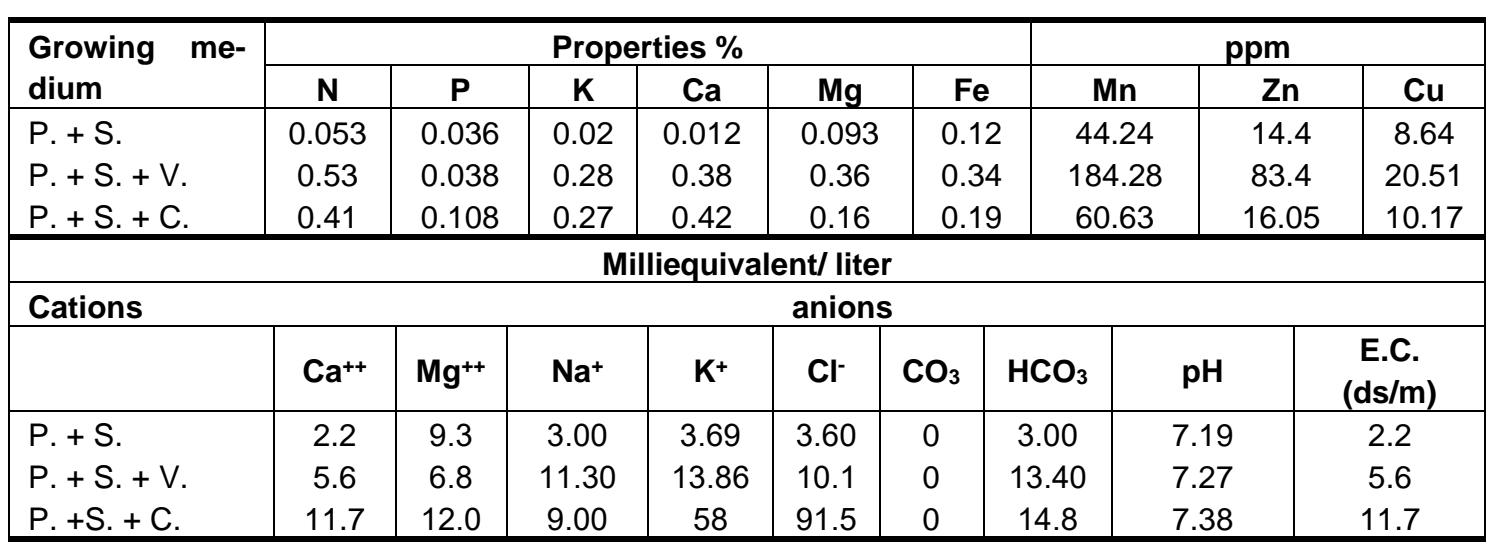

*P=Peatmoss, S=Sand, V=Vermicompost, C=Compost.

Table 2. Physical analysis of the cultivation media used in the study experiments

\begin{tabular}{|c|c|c|c|}
\hline \multicolumn{4}{|c|}{ Physical analysis } \\
\hline & O.M \% & O.C \% & $\begin{array}{c}\text { Bulk } \\
\text { density }\end{array}$ \\
\hline P. + S. & 22.4 & 11.2 & 1084 \\
\hline P. + S. + V. & 13.60 & 6.80 & 909.2 \\
\hline $\mathrm{P}+\mathrm{S} .+\mathrm{C}$. & 13.60 & 12.40 & 858.3 \\
\hline
\end{tabular}

${ }^{*} \mathrm{P}=$ Peatmoss, $\mathrm{S}=$ Sand, $\mathrm{V}=$ Vermicompost, $\mathrm{C}=$ Compost, $\mathrm{O} . \mathrm{M} \%$ = Organic matter, O.C\% = Organic carbon

\subsection{Plant material and growing conditions}

Freshly extracted seedlings of Gerbera jamesonii (cv. Jaguar Yellow) were planted on the $25^{\text {th }}$ of December in black polyethene pots $(30 \mathrm{~cm}$ width $\mathrm{x}$ 25 length) filled with different media mixture. Seedlings were placed in open nursery and watered using drip irrigation system at $2 \mathrm{~L} /$ hour.

Pots were placed in a 200-micron thickness black \& white polyethylene sheets sheet to form the gullies to collect the drained water returned to the 
catchment tank. Water was circulated by submersible pump, where a submerged pump was used to pump water up through a small floppy tube. Plants were irrigated 3 or 4 times per day in all applications depending on the calculated drainage percentage in the previous watering applications (Maloupa and Gerasopoulos 1999, Özzambak and Zeybekoğlu 2004). Biostimulants (biofertilizers) and chemical fertilizers were added as described below.

Biofertilizers. Biofertilizer (250ml of Azotobacter chroococcum and Azospirillum sp. mixture) was added one time, 15 days after planting, (Soil Application). Biofertilizer contained $10^{3} \mathrm{cfu} / \mathrm{ml}$ of Azotobacter chroococcum and $10^{3} \mathrm{cfu} / \mathrm{ml}$ of Azospirillum sp.

\subsection{Chemical Fertilizers}

Slow Release Fertilizers. Controlled-release Basacote ${ }^{\circledR}$ Plus NPK complex fertilizer (at 15:8:12 ratio plus traces elements, purchased from Shora company), with an optimal set of trace elements, was used as recommended fertilization for potting soil, substrate mixtures or top dress and plant hole fertilization. The fertilizer was added to the mixture of growing media (peat moss + sand), (peat moss + sand + vermicompost ) and (peat moss + sand + compost), at a rate of $4.2 \mathrm{~g} / \mathrm{plant} 3$ times: 30 days, 60 days after planting, and 90 days after planting.

Fast Release Fertilizers. Mineral fertilizer Kristalon ${ }^{\circledR}$, containing NPK 19:19:19 in addition to traces elements, was used as nutrient supply for the experimental plants. The fertilizer was add to the mixture of growing medium, at the rate of $2.5 \mathrm{~g} /$ plant 3 times 30 days after planting, 60 days and 90 days after planting.

\subsection{Plant parameters measurements}

Periodic Measurements were taken for each parameter such as height of seedling using (meter scale from ground level to growing tip), number of leaves per pot (counted every month up to 150 days), diameter of stem (measured every month up to 150 days by using digital Vernier caliper), fresh and dry weight of seedling (measured at the end of the season by electronic balance), length of longest tap root (measured at the end of the season from the point of initiation of roots to the tip of the root by using meter scale). Leaf greenness was determined, at the end of the season, using SPAD.

\subsection{Measured parameters}

\section{A-Vegetative growth characteristics}

1- Number of leaves/plant.

2- Number of plants/pot.

3- Leaf greenness (using SPAD).

\section{B- Flower characteristics}

1- Number of flower/ plants.

2- Flower stalk diameter/ plant (cm) using a digital caliber.

3- Flower head diameter/ plant (cm) using a graduated ruler.

\subsection{Statistical analysis}

The experiment of each season was arranged in a completely randomized design with 3 replications. Result were subjected to statistical analyses using analysis of variance (ANOVA) method. Data had been statistically analyzed using Duncan multiple range test (Duncan 1955).

\section{Results and Discussion}

3.1 Influence of growing medium treatments, mineral fertilization and biostimulant on vegetative characters

Peat is the most widely used substrate for potted plant production in the nurseries and accounts for a significant portion of the materials used to grow potted plants (Marfa et al 2002, Ribeiro et al 2007). However, sustainable horticultural production cannot rely on expensive, non-renewable natural resources such as peat (Marianthi 2006). Therefore, other materials, namely sand, compost and vermicompost, were added to the peatmoss to provide organic matter content, better aeration and more available soluble nutrients.

Table 3 shows the effect of growing medium, type of chemical fertilizer and bio-stimulants on the number of leaves, number of daughter plants and Leaf greenness of Gerbera flower plant. Results exhibited significant increases in these parameters in plants cultured in (T4) treatment, recorded the highest values in numbers of leaves (16.52 and 24.76) and values of leave greenness (39.62 and 59) in the $1^{\text {st }}$ and $2^{\text {nd }}$ season, respectively. 
Table 3. Effect of Growing medium treatments, mineral fertilization, compost and Biostimulant on number of leaves, number of daughter plants and leaf greenness (SPAD) of Gerbera (Gerbera jamesonii cv. "Jaguar Yellow"

\begin{tabular}{|c|c|c|c|c|c|c|}
\hline \multirow{2}{*}{ Treatments } & \multicolumn{2}{|c|}{ Number of leaves/plant } & \multicolumn{2}{|c|}{$\begin{array}{c}\text { Number of daughter } \\
\text { plants/pot }\end{array}$} & \multicolumn{2}{|c|}{$\begin{array}{c}\text { Leaf greenness } \\
\text { (SPAD) }\end{array}$} \\
\cline { 2 - 7 } & \multicolumn{1}{|c|}{$\mathbf{1}^{\text {st }}$ season } & $\mathbf{2}^{\text {nd }}$ season & $\mathbf{1}^{\text {st }}$ season & $\mathbf{2}^{\text {nd }}$ season & $\mathbf{1}^{\text {st }}$ season & $\mathbf{2}^{\text {nd }}$ season \\
\hline T1 & $9.12 \mathrm{c}$ & $6.52 \mathrm{e}$ & $0 \mathrm{~b}$ & $0 \mathrm{~b}$ & $26.30 \mathrm{bcd}$ & $34.62 \mathrm{bcd}$ \\
T2 & $9.52 \mathrm{c}$ & $8.6 \mathrm{~d}$ & $0.4 \mathrm{~b}$ & $0.5 \mathrm{~b}$ & $34.8 \mathrm{ab}$ & $23.59 \mathrm{def}$ \\
T3 & $8.12 \mathrm{~d}$ & $16.16 \mathrm{c}$ & $1 \mathrm{~b}$ & $1 \mathrm{~b}$ & $30.88 \mathrm{abc}$ & $27.41 \mathrm{cde}$ \\
T4 & $16.52 \mathrm{a}$ & $24.76 \mathrm{a}$ & $3.8 \mathrm{a}$ & $4 \mathrm{a}$ & $39.62 \mathrm{a}$ & $59 \mathrm{a}$ \\
T5 & $11.56 \mathrm{~b}$ & $17.36 \mathrm{c}$ & $3.8 \mathrm{a}$ & $3.9 \mathrm{a}$ & $17.89 \mathrm{~cd}$ & $47.86 \mathrm{ab}$ \\
T6 & $11.96 \mathrm{~b}$ & $21.04 \mathrm{~b}$ & $5 \mathrm{a}$ & $5.3 \mathrm{a}$ & $37.25 \mathrm{ab}$ & $37.17 \mathrm{bc}$ \\
T7 & $9.4 \mathrm{c}$ & $9.68 \mathrm{~d}$ & $3.6 \mathrm{a}$ & $3.6 \mathrm{a}$ & $3.93 \mathrm{e}$ & $6.032 \mathrm{~g}$ \\
T8 & $6.52 \mathrm{e}$ & $8.68 \mathrm{~d}$ & $0.8 \mathrm{~b}$ & $0.6 \mathrm{~b}$ & $12.57 \mathrm{de}$ & $7.68 \mathrm{~g}$ \\
T9 & $6.6 \mathrm{e}$ & $8.96 \mathrm{~d}$ & $0.8 \mathrm{~b}$ & $0.5 \mathrm{~b}$ & $3.93 \mathrm{e}$ & $10.41 \mathrm{~g}$ \\
T10 & $9.32 \mathrm{c}$ & $3.72 \mathrm{f}$ & $0.8 \mathrm{~b}$ & $0.3 \mathrm{~b}$ & $3.83 \mathrm{e}$ & $6.03 \mathrm{~g}$ \\
\hline
\end{tabular}

Means followed by the same letter in the column do not differ at the $5 \%$ probability by the Duncan test. T1: Peat moss + Sand "NPK fast-release fertilizer" , T2: Peat moss + Sand "NPK fast-release fertilizer + biofertilizer" , T3: Peat moss + Sand + Vermicompost "NPK fast-release fertilizer", T4: Peat moss + Sand + Vermicompost "NPK fast-release fertilizer + Biostimulant", T5: Peat moss + Sand + Vermicompost "NPK slow release", T6: Peat moss + Sand + Vermicompost "NPK slow release + Biostimulant" , T7: Peat moss + Sand + Compost "NPK fast-release fertilizer", T8: Peat moss + Sand + Compost "NPK fast-release fertilizer + Biostimulant", T9: Peat moss + Sand + Compost "NPK slow release", T10: Peat moss + Sand + Compost "NPK slow release + Biostimulant".

T6, containing vermicompost, slow-release NPK fertilizer and biofertilizer, recorded the highest number of daughter plants/pot, being 5 and 5.3 , in $1^{\text {st }}$ and $2^{\text {nd }}$ season, respectively. The least number of daughter plants/pot (zero) was in (T1) in both seasons.

Leaf greenness recorded the highest values in plants were cultured in (T4) in $1^{\text {st }}$ season (39.62) and in the $2^{\text {nd }}$ season (59), whereas, the least Leaf greenness values were obtained when plants were cultured in T10 Treatment in both of seasons (3.83 and 6.03 , respectively).

This study made a good comparison between different NPK mineral fertilization systems and biofertilizer used in gerbera cultivation. Research on production of gerbera generally involves applying biofertilizer and analyzing the mineral fertilizer used for the study. NPK mineral fertilizer has specific and essential functions in plant metabolism. The content of the different types of fertilization used in this research played a crucial role in flower yield and quality of gerbera plants.

Nitrogen is an essential element that has profound effects on plant growth. The form of supplied nitrogen affects plant growth and yield in both soilbased and soilless grown crops (Forde and Clarkson 1999). Nitrate and ammonium are the major sources of inorganic nitrogen for fertilization of plants. As a source of $\mathrm{N}$, a kind of chemical fertilizer which consists of $\mathrm{NH}^{4+}$ and $\mathrm{NO}^{3-}$ was used. But, under such conditions; $\mathrm{N}$ is mainly taken up as $\mathrm{NH}^{4+}$ rather than as $\mathrm{NO}^{3-}$ (Forde and Clarkson, 1999). In our study, $\mathrm{N}$ is supplied from the fertilizers which consist of mainly $\mathrm{NH}^{4+}$.

A similar study conducted on Gerbera jamesonii cv. Stanz plant, showed that bio-inoculant with combined inoculum of mycorrhiza, Azotobacter chroococcum, and Bacillus subtilus significantly increased vegetative growth characteristics; includes leaf chlorophyll intensity, leaf area, concentration of mineral elements ( $N, P, K, F e$ and $\mathrm{Zn}$ ) in gerbera leaves (Abdul-Latif and Mustafa 2019).

As a result of that, number of leaves significantly differed according to the type of growing medium and fertilization. The highest number of leaves/plant was obtained from the $4^{\text {th }}$ treatment, Table 3, which could be attributed to the addition of biofertilizer and vermicompost. The minimum number of leaves and lowest number of daughter plants per plant were observed in the $8^{\text {th }}$ and $9^{\text {th }}$ treatments, and this result may be related to the negative effect of compost and without biofertilizer.

A similar study done on gerbera cv. Natasha (Swarupa et al 2019) showed that Interaction between different growing media combinations and bi- 
ofertilizers had significant influence on growth parameters and root parameters of the studies gerbera under protected conditions. Results of that study showed that the media composed of Red soil + Coco peat + Vermicompost (1:1:1) plus biofertilizer and Vesicular Arbuscular mycorrhiza (VAM) recorded significantly maximum plant height at first flower appearance, plant height at flower harvesting stage, wider plant spread at first flower appearance and higher plant spread at flower harvesting stage and other growth parameters values.

In addition, the number of daughter plants was the highest in the $6^{\text {th }}$ treatment $(5.3 /$ plant $)$, which maybe due to the application of quick-release fertilizer and biofertilizer. This could be further supported when noticing that the lowest number of daughter plants/pot is in the $1^{\text {st }}$ treatment (0/plant) which is void of biofertilizer and fast-release fertilizer Table 3.

In terms of leaf greenness measurement (SPAD), the 4th treatment gave the highest SPAD values, which is attributed to the interaction between biofertilizers, NPK fast-release fertilizer and vermicompost, while the lowest readings (SPAD) was in $10^{\text {th }}$ treatment was obtained to the negative effect of compost as shown in Table 3. Chlorophyll contents are one of the most important criteria to determine the health of the plant, because it is directly related to physiological activities of the plant (Richardson and Simpson 2011).

\subsection{Influence of growing medium Treatments, mineral fertilization, compost and Biostimulant on Flower characters}

Data presented in Table 4 show the effect of growing medium, type of chemical fertilizer and biostimulants on number of flowers, flower head diameter and flower stalk diameter of Gerbera flower plant.

Number of Flowers was the highest in plants cultured in T4 treatment, composed to peatmoss + sand + vermicompost with fast-released fertilizer and biofertilizer, and that was in both the $1^{\text {st }}$ season (1.24) and in the $2^{\text {nd }}$ season (1.28), compared to other treatments. The effect of adding biofertilizer on flower yield can be observed when comparing treatments containing biofertilizer (T4, T6 and T8) having higher flower yield than their counter-treatments (T3, T5 and T7, respectively) which have the same formula except biofertilizer.

Moreover, Fast-release NPK fertilizer had better effect of flower yield when the growing medium contained vermicompost than same treatments but with slow-release NPK fertilizer, i.e. T3 was better than T5 and T4 was better than T6.

Flower yield of gerbera was significantly influenced by addition of compost, compared to vermicompost. Treatment which contained compost (T7, 8, 9 and 10) had less flower yield than those counter treatments containing the same combination but with vermicompost instead (T3, 4, 5 and 6), regardless of the type of chemical NPK fertilizer or the presence of biofertilizer. This could be due to the composted having less nitrogen content than vermicompost Table 1. The least number of flowers was obtained when plants were cultured in T7 treatment, in both seasons ( 0.2 and 0.16 , respectively), which contained compost but no biofertilizer.

Flower head diameter (FHD) significantly increased in plants cultured in T6 in the $1^{\text {st }}$ season (8.61) and in the $2^{\text {nd }}$ season (8.3), compared to other treatments. The lowest values of FHD were obtained in plants cultured in the T10 in the $1^{\text {st }}$ season and T10 in the $2^{\text {nd }}$ season $(1.53 \mathrm{~cm}$ and 1.08 $\mathrm{cm}$, respectively).

Compost had the same impact on FHD, as on the flower yield. Treatments T7, 8, 9 and 10 (containing compost) had smaller flower head diameter than those counter treatments (T3, 4, 5 and 6) containing vermicompost instead, regardless of the type of chemical fertilizer or the presence of biofertilizer. This could be due to the composted having less nitrogen content than vermicompost Table 1.

As for Flower stalk diameter, results showed that plant in T6 treatment had the highest flower stalk diameter of (3.46) in the $1^{\text {st }}$ season and (2.72) in the $2^{\text {nd }}$ season. Whereas, the lowest vase life values were obtained in T10 plants $(0.45$ and 0.41$)$ in the $1^{\text {st }}$ and second seasons, respectively.

The weakest flower stalk (the thickness of flower stalks) was observed in the $10^{\text {th }}$ treatment, considering the $\mathrm{P}$ content in the growing medium, while the strongest flower stalk was observed in the $4^{\text {th }}$ treatment in terms of quality characteristics of flower. 

Growth and Flowering of Potted Gerbera (Gerbera jamesonii cv. Jaguar

Table 4. Effect of Growing medium treatments, mineral fertilization, compost and Biostimulant on number of flowers, flower head diameter and flower stalk diameter of Gerbera (Gerbera jamesonii).cv "Jaguar Yellow"

\begin{tabular}{|c|c|c|c|c|c|c|}
\hline \multirow{2}{*}{ Treat. } & \multicolumn{2}{|c|}{ Number of Flower } & \multicolumn{2}{c|}{$\begin{array}{c}\text { Flower head diameter } \\
\text { (cm) }\end{array}$} & \multicolumn{2}{c|}{$\begin{array}{c}\text { Flower stalk diameter } \\
\text { (cm) }\end{array}$} \\
\cline { 2 - 7 } & $\mathbf{1}^{\text {st }}$ season & $2^{\text {nd }}$ season & $\mathbf{1}^{\text {st }}$ season & $\mathbf{2}^{\text {nd }}$ season & $\mathbf{1}^{\text {st }}$ season & $2^{\text {nd }}$ season \\
\hline T1 & $0.48 \mathrm{bc}$ & $0.84 \mathrm{abc}$ & $4.68 \mathrm{abc}$ & $5.49 \mathrm{~b}$ & $1.73 \mathrm{bc}$ & $2.37 \mathrm{a}$ \\
T2 & $0.32 \mathrm{bc}$ & $0.68 \mathrm{bcd}$ & $3.2 \mathrm{bc}$ & $5.89 \mathrm{ab}$ & $1.69 \mathrm{bc}$ & $2.09 \mathrm{ab}$ \\
T3 & $0.52 \mathrm{bc}$ & $1 \mathrm{abc}$ & $5.2 \mathrm{abc}$ & $4.11 \mathrm{bcd}$ & $2.27 \mathrm{ab}$ & $1.58 \mathrm{abc}$ \\
T4 & $1.24 \mathrm{a}$ & $1.28 \mathrm{a}$ & $4.84 \mathrm{abc}$ & $4.98 \mathrm{bc}$ & $2.36 \mathrm{ab}$ & $2.44 \mathrm{a}$ \\
T5 & $0.36 \mathrm{bc}$ & $1.08 \mathrm{ab}$ & $4.92 \mathrm{abc}$ & $5.47 \mathrm{~b}$ & $2.38 \mathrm{ab}$ & $2.40 \mathrm{a}$ \\
T6 & $1.08 \mathrm{a}$ & $1.04 \mathrm{ab}$ & $8.61 \mathrm{a}$ & $8.3 \mathrm{a}$ & $3.46 \mathrm{a}$ & $2.72 \mathrm{a}$ \\
T7 & $0.2 \mathrm{c}$ & $0.16 \mathrm{e}$ & $2.90 \mathrm{bc}$ & $2.44 \mathrm{cde}$ & $1.17 \mathrm{bc}$ & $0.93 \mathrm{~cd}$ \\
T8 & $0.24 \mathrm{c}$ & $0.2 \mathrm{e}$ & $2.04 \mathrm{bc}$ & $1.38 \mathrm{de}$ & $1.07 \mathrm{bc}$ & $0.59 \mathrm{~cd}$ \\
T9 & $0.28 \mathrm{bc}$ & $0.28 \mathrm{de}$ & $6.6 \mathrm{ab}$ & $2.46 \mathrm{cde}$ & $0.95 \mathrm{c}$ & $1.03 \mathrm{bcd}$ \\
T10 & $0.28 \mathrm{bc}$ & $0.28 \mathrm{de}$ & $1.53 \mathrm{c}$ & $1.08 \mathrm{e}$ & $0.45 \mathrm{c}$ & $0.41 \mathrm{~d}$ \\
\hline
\end{tabular}

Means followed by the same letter in the column do not differ at the $5 \%$ probability by the Duncan test. T1: Peat moss + Sand "NPK fast-release fertilizer" , T2: Peat moss + Sand "NPK fast-release fertilizer + biofertilizer" , T3: Peat moss + Sand + Vermicompost "NPK fast-release fertilizer" , T4: Peat moss + Sand + Vermicompost "NPK fast-release fertilizer + Biostimulant", T5: Peat moss + Sand + Vermicompost "NPK slow release", T6: Peat moss + Sand + Vermicompost "NPK slow release + Biostimulant" , T7: Peat moss + Sand + Compost "NPK fast-release fertilizer", T8: Peat moss + Sand + Compost "NPK fast-release fertilizer + Biostimulant", T9: Peat moss + Sand + Compost "NPK slow release", T10: Peat moss + Sand + Compost "NPK slow release + Biostimulant".

In a similar study, (Abdul-Latif and Mustafa 2019), bio-inoculation of Gerbera jamesonii cv. Stanz with combined inoculum of mycorrhiza, Azotobacter chroococcum and Bacillus subtilus significantly increased flowering characters, including length of flower stalk, diameter of flower, capitulum diameter, flower dry matter \%, number of flowers and vase life (28.52 days).

\section{Conclusions}

The use of vermicompost and biostimulants in the potting media for gerbera flower plant showed a significant increase in plant characteristics and flower quality. Fast-release NPK fertilizers showed to have better impact on growth and flower parameters, in the presence of vermicompost, compared to Fast-release NPK fertilizers treatment with compost.

\section{References}

Sawsan A Abdul-Latif; Hemn A Mustafa (2019) Effect of Biofertilizers and Carbolizer on Growth of Gerbera Plant (Gerbera jamesonii). Plant Archives 19, 1733-1754.
Anderson, R (2019) Landuse and soil property effects on infiltration and soil aggregate stability In the Lower Mississippi River Valley. In Landuse and Soil Property Effects on Infiltration in the Lower Mississippi River Valley. MS. Thesis, Univ Arkansas, Fayetteville.

Atefe, A; Ali, T; Mahmoud, Sh; Gholam H Davarynejad (2012) Study of the Effect of Vermicompost as One of the Substrate Constituents on Yield Indexes of Strawberry. J Hortic Sci Ornamental Plants 4, 241-246.

Bhat, MI; Rashid, A; Rasool, F; Mahdi, SS; Haq, SA; Bhat, RA (2010) Effect of Rhizobium and VA-mycorrhizae on green gram under temperate conditions. Res Agric Sci 1, 113-116.

Brar, SK; Sarma SJ; Chaabouni, E (2012) Shelf-life of Biofertilizers: An Accord between Formulations and Genetics. J Biofertil Biopestici 3, e109.

Brun, R; Settembrino, A; Couve, C (2001) Recycling of nutrient solutions for Rose (Rosa hybrida) in soilless culture. Acta Hortic 554, 183.

Duncan, DB (1955) Multiple Range and Multiple F Test. International Biometric Society 11, 1-42. 
Florance Flora, Ganesha Temple Road, Sahakarnagar (2018) www.floranceflora.com.

Forde, BG; Clarkson, DT (1999) Nitrate and ammonium nutrition of plants: Physiological and molecular perspectives. Adv Bot Res 30, 1-90.

Hari, M; Seshadri, S; Perumal, K (2010) Biofertilizer (Phoshpobactaria). Shri Aam Murugappa Chettiar Researc Center, Taramani, Chennai pp 1-16.

Leoni, B; Loconsole, D; Cristiano, G; De Lucia, B (2019) Comparison between Chemical Fertilization and Integrated Nutrient Management: Yield, Quality, N, and P Contents in Dendranthema grandiflorum (Ramat.) Kitam Cultivars Agronomy 9, 202.

Maloupa, E; Mitsios, L; Martinez, PF; Bladenopoulou, S (1992) Study of substrates used in gerbera soilless culture grown in plastic greenhouse. Acta Horticulturae 232, 251-259.

Maloupa, E; Gerasopoulos, D (1999) Quality production of four cut gerberas in a hydroponic system of four substrates. Acta Horticulturae 486, 433-438.

Marfa', O; Lemarie, F; Ca'ceres, R; Giuffrida, F; Gue' rin, V (2002) Relationships between growing media fertility, percolate composition and fertigation strategy in peat-substitute substrates used for growing ornamental shrubs. Sci Hortic 94, 309-321.

Marianthi, T (2006) Kenaf (Hibiscus cannabinus L.) core and rice hulls as components of container media for growing Pinus halepensis M. seedlings. Bioresour Technol 97, 1631-1639.

Motlay, I; Genc, C; Gürsan, K (1998) Gerbera yetiştiriciliğinde en uygun harç ve ticari gübre isteğinin saptanması. I. Ulusal Süs Bitkileri Kongresi S 119-127.
Özzambak, E; Zeybekoğlu, E (2004) Serada Topraksız Gerbera Yetistiriciliği ve Bazı Yetistirme Ortamlarının Karsılastırılması (Arastırma Sonuçları). İzmir Ticaret Odası Yayın No. 140, İzmir.

Savithri, P; Khan, HH (1993) Characteristics of coconut coir peat and its utilization in agriculture. $J$ Plant Crop 22, 1-18.

Javed, S; Panwar, A (2013) Effect of biofertilizer, vermicompost and chemical fertilizer on different biochemical parameters of Glycine max and Vigna mungo, Recent Research in Science and Technology $5,40-44$.

Suthar, S (2009) Impact of vermincompost and composted farmyard manure on growth and yield of garlic (Allium sativum L.) field crop. International of Plant Production 3, 27-38.

Swarupa, N; Lakshminarayana, D; Prasanth1 P; Saida Naik, D (2019) Influence of Different Combinations of Media and Bio Fertilizers on Growth of Gerbera cv. Natasha under Protected Conditions. Int J Curr Microbiol App Sci 8, 2797-2804.

Ribeiro, HM; Romero, AM; Pereira, H; Borges, P; Cabral, F; Vaconcelos, E (2007) Evaluation of a compost obtained from forestry wastes and solid phase of pig slurry as a substrate for seedlings production. Bioresource Technology 98, 3294-3297.

Richardson, AE; Simpson, RJ (2011) Soil Microorganisms Mediating Phosphorus Availability. Plant Physiology 156, 989-996.

Yassen, AA; Khalid, KhA (2009) Influence of organic fertilizers on yield, essential oil and mineral content of onion. International Agrophysics 23, 183188. 
تأثير معلاملات التسميد والمحفزات الحيوية على نمو وإزهار نبات الجربيرا (Gerbera jamesonii) cv. “Jaguar Yellow”

[84]

\author{
إسلام عبدالمنعم أحمد على1"- أيمن فريد أبو حديد2- سهير السيد حسن2- \\ أحمد عبدالوهاب محمد عبدالحافظ3- - محمد هويدى رمضان2 2 \\ 1- معهد الدراسات العليا والبحوث الزراعية بالمناطق القاحلة - جامعة عين شمس - القاهرة - مصر \\ 2- قسم البساتين - كلية الزراعة - جامعة عين شمس - صندوق بريد 68 - حدائق شبرا 11241 - القاهرة - مصر \\ 3- قسم الميكروبيولوجيا الزراعية-كلية الزراعة - جامعة عين شمس - صندوق بريد 68 - حدائق شبرا 11241 - القاهرة -
}

*Corresponding author: somaa4220@gmail.com

Received 10 September, 2020

Accepted 9 October, 2020

أصص الجربيرا. أشارت النتائج إلى أن بيئة النمو المكونة

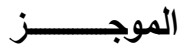

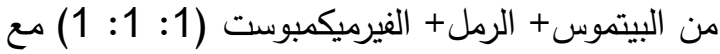

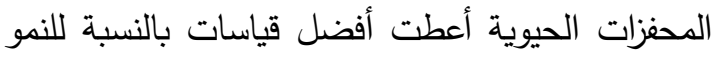

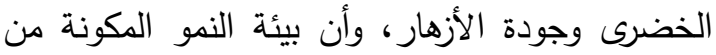

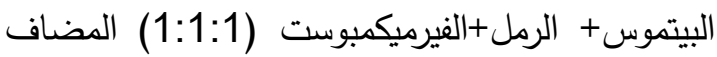

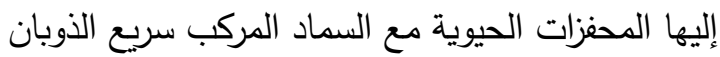
أعطت أزهار ذات صفات جيدة، بينما السماد المركب السب السبان

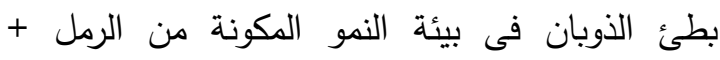
البيتموس + الفيرمكبوست مع المحفزات الحيوية أعطى لنئ

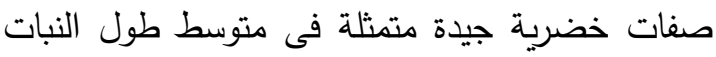

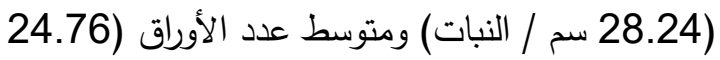

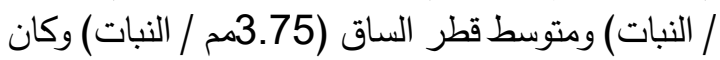
متوسط الوزن الطازج للنبات (47.87 جم / النات / النبات)

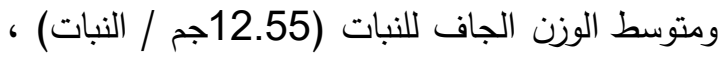

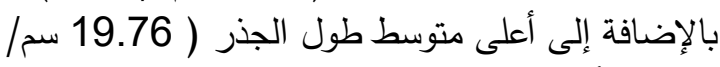

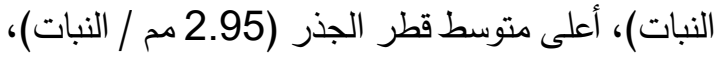

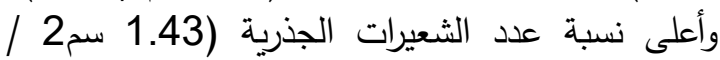
النبات) ، نسبة الإخضرار فى الأوراق ( 57.2 ) وأعلى 1.43 عدد الخلفات (5 / النبات).

هدفت هذه الدراسة إلى تقييم تأثير أنواع التربة

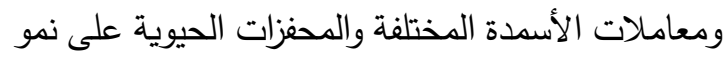
وإزهار نبات الجربيرا ( Gerbera jamesonii cv. Jaguar Yellow). تم إجراء هذه الدراسة خلات

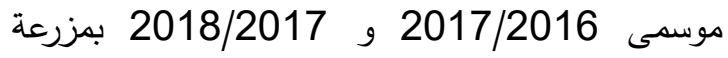
معهد الدراسات العليا والبحوث للزراعة فى المناطق

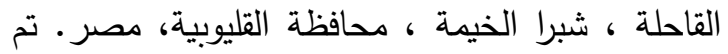
تتفيذ التجربة بتصميم تام العشوائية (CRD) فى ثلاث الثراث مكررات، والنتائج النهائية خضعت لتحتئ لتحليل التباين (ANOVA)

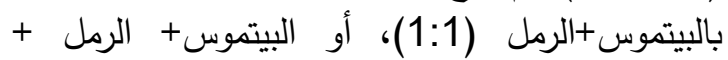

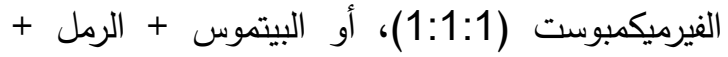
الكمبوست (1:1:1) مع أو بلدون المحفزات الحيوية النمبية

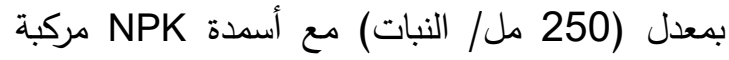
بطيئة الذوبان بمعدل (4.2 جم / النبات) أو أسمدة مركية سريعة الذوبان بمعدل (2.5 جم / النبات) لتحديد تأثير الأن آندان الأسمدة المختلفة والمحفزات الحيوية على نمو وإزهار 